\title{
New Directions-a Ministerial Review in Review
}

\author{
Michael Lanphier
}

\begin{abstract}
The Ministerial review, Building on a Strong Foundation for the 21st Century: New Directions attempts to solidify certain recommendations from the December 1997 Not Just Numbers report of the Legislative Review Advisory Group. The present review does not qualify as a "white paper" as its guidelines are suggestive and incomplete, rather than being convertible into an integrated set of legislative proposals in a parliamentary bill. Its guidelines stress the need for greater and more transparent accountability of immigration regulations and administration. This emphasis is evident both for immigration and refugee policy, the latter to be distinguished by creation of a special Protection Agency. Protection, a term undefined in the document, is twinned with control of abuse as administrative preoccupations. Overall, the guidelines stress administrative vigilance over humanitarian objectives to which Canada is committed as signatory to many international instruments.
\end{abstract}

\section{Précis}

Le rapport ministériel intitulé De solides assises pour le $21^{e}$ siècle: Nouvelles orientations s'efforce d'affermir certaines des recommandations du rapport Au-delà des chiffres de décembre 1997 émanantdu Groupe Consultatifsur la révision de la législation. Ce rapport ne mérite pas la désignation de "livre blanc» car ses directives sont suggestives, incomplètes, et difficilement convertibles en un corps de législation pouvant s'intégrer dans un projet de loi parlementaire. Ses directives mettent en relief le

Michael Lanphier is Professor of Sociology at York University and faculty associate of Centre for Refugee Studies, where he serves as Editor of Refuge. His research focuses on Canadian immigration and refugee policy and service deliveries by non-governmental organizations. besoin d'une responsabilisation plus netteet plus transparente des règlements d'immigration et de leuradministration. Cettemise en reliefest évidente dans le cas de l'immigration et des politiques en matière de réfugiés, ces dernière se voyant distinguées par le projet de création $d^{\prime} u n e$ agence spéciale deprotection. Cette protection-le terme n'est pas défini dans le document -est jumelée à l'idée du contrôle des abus comme préoccupation administrative. En gros, les directives valorisent la vigilance administrative au détriment des objectifs $h u$ manitaires qui sont normalement la vocation du Canada en sa qualité de signataire d'un grand nombre d'ententes internationale.

\section{From Legislative Review to New Directions}

\section{A. Report of Legislative Review}

The Legislative Review, whose advisory group was established in November, 1996, finally submitted its report, Not Just Numbers: A Canadian Framework for Future Immigration, some 13 months later, at the end of December, 1997. Its 172 recommendations cut a wide swath through the domain of immigration and refugee policy and law. Its effects at once aroused heightened interest among those active in immigration and refugee affairs and focused attention upon administrative arrangements from design through implementation of programs.

The three principals of the Advisory group and their staff invited oral presentations and written submissions from a wide variety of interested and expert groups. This wealth of material was organized into a lengthy report and further distilled into an executive summary of recommendations.

The following articles treat mainly those sections of the report touching refugees, although a hard and fast line cannot be drawn since certain recommendations (e.g., family reunification) cut across all immigration categories. This Legislative Review energized vociferous and sustained response throughout Canada among those interested in immigration and refugee issues-so great as not only to alter the ministerial timetable for converting the report into legislative proposals but to force a reconsideration of the thrust of the very report.

In the Minister's formal response, Building on a Strong Foundation for the 21st Century, forwarded a year later in January 1999, the results of the Legislative Review Advisory group's reportas well as consultations have been converted into "an ongoing process." Instead of the report's recommendations being definitive, they are now interpreted as the first step in setting "broad directions" in a "coherent [and] comprehensive package."

Those recommendations most closely related to refugees and those admitted under other humanitarian auspices derive from the recommendation to separate issues of refugee protection from those relating to immigration and settlement of persons in other classes (independent, entrepreneurial, family).

\section{B. "White Paper" or "Green Paper"?}

Presumably, the ongoing process of policy review will lead within the near future to specific legislative proposals. The Minister has referred to the recent report, Building on a Strong Foundation for the 21st Century: New Directions for Immigration and Refugee Policy, as a "white paper."1 According to the British common-law tradition adopted in Canada, a "white paper" contains sections or paragraphs which would quickly convert intolegislative proposals for parliamentary debate. This interpretation appears somewhat more advanced in the legislative process than the textitself allows. The report contains 
"Proposed Directions" and specifications of issues and items to be addressed in possible legislation. Butboth the tone and substance lie some distance from the precision and concreteness required for legislation.

While the paper does not qualify under the British "white paper" standard, neither does it fall neatly into the "green paper" category of a wide-ranging attempt to set a frame within which policy may be fashioned. The report lies somewhere between the two typical forms of policy papers.

The proposals indeed attempt to come to terms with specific issues. Formally, the report insists on a methodology to render more transparent a complicated and sometimes convoluted series of inquiries. The proposal, for example, to render into a single inquiry and decision the present threestep procedure for determining 1) refugee status determination; 2) postdetermination risk review; and 3) riskrelated humanitarian review, consolidates a presently cumbersome and time-consuming process. It is innovative as much for its method as substantive and administrative impact.

What major changes have there been in the 20-year period since the enactment of Canada's present Immigration Act? The sheer volume of immigration to Canada has increased overall, and most notably in the component labelled " $\mathrm{hu}$ manitarian" including refugees. At the time of drafting the Act (1976), refugees arrived irregularly and in small numbers, rarely more than 5,000 persons per year in the early to mid-1970s. Refugee claimants were an unknown quantity. Further, the effects of the rapid increase in transportation and communication efficiency on the movement of peoples and their ability to reach the formerly remotely located Canada were not foreseen. Finally, the interdependency between immigration flows and global and regional developments have loomed far more important in the late 1990s. Thus immigration policy becomes even more an instrument of political, economic and social control in an arena where Canada is so closely interlinked with all other nation-states.
The New Directions report, in its attempt to highlight the changes which the Minister considers of primary importance, fails to indicate what disposition would be made to provisions presently in the Immigration Act (as modified) but which arenotmentioned. Dothey remain untouched regardless of implications arising from those provisions which are recommended for change? It is therefore difficult to discern whether absence of commentary on a given provision implies concurrence with the status quo or whether another report will follow with fuller specification. In any event, the New Directions report both fails to meet the traditional precision of a White Paper and remains incomplete.

\section{New Directions: An Oxymoronic Challenge}

The Minister's challenge, as enunciated in the White Paper appears almost oxymoronic. It is necessary to develop revisions to the existing Immigration Act which contribute to social cohesion and economic well being, reflect Canada's tradition of humanitarianism and reflect Canadian values. The values for this reformulation underscore family as a basis of security and social stability, a mutually supportive citizenry with respect for mutual rights and obligations, respect for personal honesty, social diversity and formal institutions. Simultaneously, the revisions must render the Immigration Act more transparent in its implementation, facilitate smooth and quick entry of newcomers after careful security screening.

It would require thejudgment of Solomon and the astuteness of Montesquieu in order to provide revisions to remake the Immigration Act into a series of seamlessly interconnected provisions, conforming to the enunciated value structure. Yet thesebureaucratic admonitions are issues without a compensating attention to the urgency and humanitarian need of many migrants whose destination to Canada has been forced by circumstances of persecution and social upheaval. While every nation-state as a matter of enlightened selfinterest opts for an immigration intake which promises to improve the quality of its population and augment its national productivity, they also recognize the obligation to reach out to refugees and other forced migrants for whom political circumstances have dictated exodus. This humanitarian component is integral to every immigration policy, not least that of Canada, which boasts of its compassionate record.

Moreover, in addition to Canada's Charter of Human Rights, mandating certain rights and obligations of persons in this country, Canada is signatory to international instruments, such as the Geneva Convention and the Convention against Torture. They require Canada as part of its international commitment to human rights to assume a variety of responsibilities to accept refugees regardless of their prospects for economic self-improvement or for possible implications for long-term care. Thus humanitarian action in resettlement in Canada moves hand-in-hand with compliance required in the international arena.

In the world of day-to-day bureaucratic administration of refugee policy, how might revisions stand any chance of rendering the highly desirable outcome of intake efficiency, thoroughness in screening and compassion in light of the unrelieved procession of world crises? Only a limited number of options are available, which we shall examine in turn.

\section{A. Decentralizing Authoritative Decision-making}

The Ministry of Citizenship and Immigration might decentralize many of the functions currently the prerogative of its own department. Several possibilities aresuggested throughout the report. Provinces may assume enhanced responsibilities in selection of immigrants in various categories. Specificindividuals and groups may be nominated as either prospective employees or sponsored with the expectation of rapid turnaround between arrival and employment at the option of the respective provinces. Analogous schemes for family reunification might similarly be decentralized to provincial ministries. 
For refugees, decentralization to provincial level appears more complex. The respective provinces would have to furnish representatives abroad for selection while in-province authorities coordinate this activity with reception, orientation, housing and initial resettlement.

Non-governmental organizations (NGOs) would assume a much strengthened role. Those NGOs linked with an international service organization would be called on to screen migrants forcibly removed from their homelands or villages. Decision on eligibility and selection would involve at minimum a tripartite group: NGO, provincial and federal representatives. $A$ division of labour would have to be struck on responsibilities for safety, transportation, health and security clearances. Responsibility to assure family reunification would have to be similarly allocated.

Within Canada, resettlement activity would have become exclusively a provincial responsibility. Provinces, in turn, might delegate responsibility to NGOs and/or to major municipalities. Municipalities, in turn with collaboration of NGOs, would decide on initial placement of families/households and responsibility for allocation of services during initial months after arrival. ${ }^{2}$

It is clear that decentralization would evolve additional responsibility upon newcomers themselves. They would have to assure provision of documents and information, decide quickly on family matters and intervene in timely manner to maximize the possibility of filling their needs and preferences.

Despite the emphasis on certain decentralized activity, the role of UNHCR determination activities are not mentioned. It is notclear whether the government intends to depend more upon UNHCR offices for recommending likely candidates or whether their screening processes may substitute for those which Canadian officials abroad currently assume. Articulation with international bodies and legal instruments is only briefly alluded to in connection with its commitment to re- spect protection needs provided in the Conventionagainst Torture.

\section{B. Centralizing Authoritative Decision-making}

Against the backdrop of provisions for decentralizing decision-making noted above, New Directions in the overall strengthens the centralizing authority inherent in the current policy in refugees. This current is evident in the structure of proposals as well as in the discussion of means to streamline policy in an age of increasing information and technological sophistication. As the thrust of the report stresses this centralizing tendency, especially with reference to refugee policy, the remainder of this article addresses these tendencies as they bear implications for the two "streams" of would-be refugees: those selected overseas and those making inland claims in Canada.

\section{"Strengthening Refugee Protection"}

The report continues very much in line with the recommendations of the Advisory Group which appeared in Not Just Numbers. Refugee protection is identified as an undertaking separate from immigration. Accordingly, a separate section is devoted to issues specific to refugees as persons not only seeking admission to Canada as newcomers, but more importantly uniquely requiring protection. Both versions agree that protection as an issue should take priority over selection for resettlement in Canada. Certain refugee groups might be better accommodated by Canada's assisting in local settlement in a neighbouring country, both versions allow. The 1999 New Directions report distinguishes two areas of reform, corresponding to the venue where would-be refugees initially make their claim to a Canadian government official: overseas or inland. The term "protection", however, is nowhere defined. Its meaning has to be derived from the context in which the term appears.

\section{Overseas Refugee Resettlement}

Details as to the conditions under which the latter option, protection without re- settlement in Canada, would be chosen are not offered. Thus the reader must consider this as a general policy statement without implications as to the quantity, origins or quality of refugee intake abroad. Nocriteria are offered on which to decide what groups or individuals would be selected among all those deemed eligible for admission as refugees for resettlement in Canada. This issue raises nontrivial questions regarding resource allocation in refugee protection. Should more resources be devoted to assisting neighbouring countries accommodate refugees seeking asylum than presently offered in Canadian foreign policy, for example? More concretely, to what extent would strengthening of protection through such assistance for local settlement draw resources from Canada's existing resettlement activities? In that sense, the "protection" and "resettlement" activities may compete for the same resources.

Canada's commitment to overseas resettlement cannot proceed with any degree of greater efficiency or volume if the number and location of visa-granting posts abroad is not greatly redistributed and augmented. In the regions of the world which produce many if not most of the world's refugees, visa offices are either remote or inaccessible to those in flight. In the whole of the African continent, for example, only three visa posts may be found. Thus most refugees in Africa cannot reach a Canadian post. Canadian visa officers who visit camps likewise find distances remote, requiring several days out of the office even for travel. Intake abroad thus remains sporadic and low for want of sufficient offices established with proximity to refugee-producing regions.

\section{Protection}

Substantively, protection is only briefly sketched. A typology for occasions for refugee determination abroad is not articulated. Such a typology is much needed in order to show what kind of "new directions" are implied by the identification of protection as a separate function. Without such specification, the distinction amounts to little more than a minor clarification. 
Despite ambiguity in definition or delimiting "protection" as an essential function, the report enumerates several administrative modifications which, if enacted, will greatly ease difficulties experienced by refugees seeking status abroad. Notably, immediate action in cases of urgency and a more expeditious implementation of (immediate) family reunification appear as important agenda items. For the former, action in cases of urgency, the case appears selfevident. Its very appearance raises questions as to why the government may have been insensitive to such instances in the past.

In the case of the "Women-at Risk" program, part of its slow and halting implementation has resulted from the incapacity of the government to move quickly to remove women from dangerous situations (Spencer-Nimmons 1994). Admittedly, assistance in cases of urgent need requires additional governmental personnel and closer working ties with NGOs and international agencies to identify cases and the typeof need. Greater resources (especially human) will have to be dedicated to this urgent protection task in a variety of venues of civil upheaval and mass persecution throughout the world. Prompt admission to Canada also requires support of agencies within Canada to assist persons at the moment of arrival and to "follow through" on emergency and longer-term service deliveries to such persons.

\section{Family Reunification}

New Directions offers important (and long-awaited) observations on the importance of family reunification for those refugees selected abroad. Without providing necessary detail, the text refers to "ensur[ing] promptness in immediate family reunification." Presumably, efforts would be made to gather members of the immediate family together prior to arriving in Canada.

The observation on immediate family reunification appears self-evident. Difficulties arising from arrival and adaptation to Canada would be immeasurably alleviated thereby. Yet this matter is far from simple: there may be important reasons for deferring family reunification, such as the wish of the family head to establish a "beachhead" in the host country (Canada) before bringing the rest of the family. This pattern of migration has of course been characteristic of immigration to North America throughout the past century. Nevertheless, more recent history of refugee migration has been filled with delays in family reunification for reasons often relating to bureaucratic procedure, to the disadvantage and sometimes outright danger of those left behind to languish in camps or other unwelcoming temporary settings. Explicit commitment to family reunification, albeit with the limitation to "immediate" members, therefore marks an important humanitarian policy advance.

\section{Official Period for Resettlement}

For the past two decades, administrative convention has postulated twelve months as the formal or "official" resettlement period following arrival in Canada of refugees selected abroad. However convenient for administrative purposes, refugees and sponsors have complained that in many if not most cases, a period of twelve months is insufficient for the initial phase of resettlement. This is true, despite the fact that Canada's official period stands among the longest among resettlement countries. If language training precedes job search, for example, a twelve-month period is often insufficient for developing language mastery adequate for any but jobs requiring little verbal and no written interaction. Moreover, refugees may arrive with experience of significant trauma-torture or abuse. In such cases, initial resettlement may be indefinitely protracted.

In recognition of the variety of difficulties inherent in initial refugee resettlement, the New Directions report refers to a "longer period" required, without specifying an upper limit. Doubtless further legislative drafting will have to establish a limit. Yet the brief paragraph in the report signals an important change cognizant of the realities of adaptation to the new host country.
The New Directions report calls for greater coordination in overseas refugee selection with non-governmental organizations (NGOs). Again, formal recognition is awarded to practices that have existed informally for a few decades. In any event, such arrangements adumbrate a "triangulation" of activity abroad: federal government (perhaps accompanied by provincial representatives) would coordinate its selection activities with UNHCR and other international organizations and with NGOs with well established networks in various countries. The fund of experience with local conditions and needs of refugee populations will be greatly enhanced. Selection criteria may be broadened with sensitivity to refugee needs as well as those of the state.

\section{Inland Refugee Claims: From Protection to Determination}

In the cases of persons seeking refugee status upon arrival in Canada, the report shifts emphasis from protection to determination. Apparently, the very presence of a person physically present in Canada seeking refugee status constitutes prima facie evidence of protection. As signatory to the UHNCR Convention, Canada is pledged to observe non-refoulement: persons will not be removed to the country in which persecution occurred or is apprehended.

The issue must be further qualified, however, since those claiming refugee status are not accorded such status until after due process of determination. "Protection" therefore refers to nonrefoulement and assurance of this due process, rather than the award of rights to obtain landed status in Canada and assurances against removal for lack of that status and rights to work, schooling and a range of social benefits. The burden of proof to establish refugee status remains with the claimant, who must convince a refugee determination board of the legitimacy of his/her claim according to prevailing procedures and regulations.

Canada also has a corresponding obligation to facilitate resettlement of claimants once their claim has been adjudicated and approved. In the case

Refuge, Vol. 18, No. 1 (February 1999) 
3.

of inland claimants, several iinpediments presently exist, for which few if any remedies have been offered in these recommendations. Claimants whose documentation appears insufficient or missing may be kept waiting for long periods of time without appropriate governmental action. Similar fate awaits those who cannot muster the requisite "Right-of-Landing" fee as well as those who are suspected of security or health risk. The New Directions report recommends the change of a maximum waiting period of five years to three. Yet no means is suggested for expediting such administrative blockages which currently leave such claimants unsuccessful in establishing a claim in limbo.

"Consolidated Decision-making" In order to streamline what has become an extraordinarily complex series of steps for claim adjudication, the report proposes to collapse three discrete processes into one single decision under a single body of decision makers. This body strengthens the present Immigration and Refugee Board, which would be charged in a single ruling with the three decisions. These include deciding upon the need for protection under those instruments to which Canada is signatory (including the Geneva Convention). The Board would simultaneously humanitarian and compassionate circumstances for admission to Canada. As a result, the present three steps of determination, post-determination risk review and risk-related humanitarian review would be collapsed into a single decision labelled "protection."

The recommendations also restrict the time frame within which the claim may be lodged to 30 days after arrival. Within the context of improving administrative efficiency, the provision appears almost self-evident. There is no allowance, however, for delay in cases of missing information or circumstances impeding the claimant's ability to identify him- jherself as one requiring protection.

Administratively, this process appears clean and neat. Certainly, the speed of the full decision-making process currently in place will be greatly accelerated. These provisions as presently sketched eliminate any change for review or "second thought" of the first (and apparently final) decision. There does not appear to be any recourse for appeal against possible irregularity in application oflegal procedure, as presentlyavailable.

What procedures assure that such streamlining will result in fairness as well as efficiency? The text provides for a "more comprehensive front-end screening of claims. This screening is specified to occur promptly-within 30 days after arrival in Canada in all but "compelling situations." In this manner, only those claims initially judged to appear legitimate to presentlyunspecified officers will go forward to this comprehensive review.

The New Directions report goes to some lengths to specify types of administrative efficiencies in detecting "manifestly unfounded" claims. Those with reasons unrelated to persecution and those coming from countries with no known refugee production will be processed on a priority basis. These provisions, presumably to deport such persons without delay prior to reaching the full determination process, are introduced to expedite the "flow through" of apparently well-founded cases. For origin from "safe countries," this screening appears to be categoric, rather than individual. There is no specification for accommodating persons who claim persecution from these presumably "safe" countries.

Nor is there attention to the definition of" safe" countries other than reference to countries which are signatory to the UN Convention. Yet not all countries treat those being returned uniformly. Canada cannot be sure that a would-be claimant returned to the country where he or she might first have established a claim would in fact be allowed to remain there. That country could well return the person to a country with a known record of persecution according to Canada's reckoning. The notion of "safe" Third Country is seriously flawed. The New Directions report pro- vides no further clarification of Canada's policy stand or administrative resolve to "protect" those who might be subjected to a chain of rejections ultimately returning them to the very country from which they sought relief from persecution.

The screening-process proposals remain vague on several points. What governmental office and which officers will conduct such a front-end screening? How would these officers be so qualified? What kind of assistance (qualified interpreters, legal counsel, UNHCR representatives) would be available to claimants in this screening?

In case of negative decisions, no less urgent questions likewise surface. The New Directions report is silent on questions such as whether persons whose cases are decided negatively offered any recourse before being deported Again, provisions for those claiming status from a country known to be persecuting certain categories of its residents and citizens are not specified. What kind of remedies would be available under preremoval risk assessment? Appeal procedures would continue to be restricted to issues of law, without provision for appeal on the merits of the case in such instances as the late arrival of information with a crucial bearing of the possible favourable determination decision.

\section{Ministerial Discretion}

It is clear that New Directions offers the Minister's office increased unilateral latitude in decision making at several important junctures with respect to inland refugee determination. First, it is proposed that the Minister have the right to intervene in the IRB refugee determination process. This intervention is a new power since the present provisions call for "arm's length" relationship between IRB and governmental process. Second, the Minister could selectcases for "vacation" : i.e., the authority to recommend (to IRB) revocation of refugee status. ${ }^{3}$ Such cases might include those in which some misrepresentation was believed to occur during the determination process. As well, refugee status would "cease" under speci-

Refuge, Vol. 18, No.1 (February 1999) 
fied conditions, such as voluntary repatriation to the home country.

The report suggests that the bluntness of this unilaterality might be mitigated in two ways. First, criteria and process for selection of decision makers might be introduced. Secondly, the existing advisory committee to advise the minister on appointments might have their role clearly specified. ${ }^{4}$

Nevertheless, the scenario provided by the provisions for ministerial intervention in cases of refugee determination demonstrates clearly the enhanced role of the minister. The scope of control appears wider with few checks on discretionary powers. Little place for accountability to the interested public appears in the report, and even those instances of mediated accountability (through the advisory council) are couched, even grammatically, in conditional terms.

\section{Security Issues}

"Protection" as a leading motif of New Directions brings with it renewed concern on the part of the Canadian government for improved and heightened security. Canadian immigration and refugee intake being among the highest per capita in the world, opportunists and others are eager to circumvent regulatory controls to gain entry either for themselves or for the purposes of trafficking in human cargo. Security issues are bound to be a high governmental concern, not least since borders appear to be closing to would-beclaimants and asylum-seekers throughout the developed world. Canada therefore looms larger as one of the remaining points of entry to the developed world.

In light of changing worldwide reactions, balancing Canada's security concerns with compassion for asylumseekers who feel pressed to flee under any circumstances and lacking appropriate identity papers continues to grow more delicate with each passing year if not month. Any intake stream may be infused with smuggled people (sometimes with smuggled contraband), inadequate or missing documentation and health problems, all of which are perceived as threats to security of the Canadian government and its citizenry.

The report acknowledges that a wide-ranging set of corrective security measures is the requisite remedy. Ramifications exist not only for active perpetrators (smugglers, those misrepresenting themselves and their pur poses) but for those more passively involved, including claimants with improper or missing documentation.

In order to protect against form of exploitation now common in peopletrafficking, the report recommends establishment of new classes of inadmissibility. These would exclude members of governments already sanctioned by Canada, people smugglers and those who make false statements on permanent residence applications.

The most inclusive set of security measures arises with respect to improper documentation on arrival. As a response, the government proposes to enhance collaboration with other countries in sharing data on illegal migration and to enable prosecution of persons assisting in illegal migration.

Among the most disadvantaged among potential arrivals are those fleeing with insufficient personal and material resources who fall easy prey to such trafficking schemes. A vigorous clampdown would therefore have the untoward effect of barring some of the world's most vulnerable - those most in need of a durable solution. Ignoring security threats, on the other hand, patently invites predators to "pounce for the kill" if Canada lacks vigilance.

As if to "balance" Canada's reputation for generosity in intake, New Directions proposes several security enhancements. These include interdiction of improperly documented persons prior to disembarking in Canada, more precise specification of inadmissibility of classes of people. Such classes include those linked with governments already negatively sanctioned by international multilateral bodies such as the UN. Obviously, known traffickers in human cargo and those making false declarations of their status or behaviour would likewise be excluded categorically.
Those with inadequate or falsified documentation constitute a less decisive category of security risk or breach. Many, if notmost, (would-be) refugees fleeing a terrorist persecutory régime cannot possibly obtain appropriate documentation. They invariably purchase bogus papers through some intermediary whose activities are not only illegal but may well be extortionist. These victims therefore become tainted through their connections to procure illgotten papers. The proposed remedy takes harsh action against those who refuse cooperation in attempt to establish identity. They would be detained with review at periodic intervals.

Looming over these security concerns are possibilities of vastly widened information surveillance through improved technology such as scanning. The government will explore the possibilities of scanning all documents of travellersen route to Canada. Thus even if documentation were destroyed, images would be retained. Implications for vulnerable persons who have to obtain bogus papers in flight for lack of appropriate documentation from the home country are notmentioned. Such victims of the flourishing trade in false documentation would face detention and criminal investigation on arrival in Canada. It is not clear how their situation might be protected while prosecution of perpetrators of such false documentation and extortion advances.

\section{Appeal System}

New Directions traces few if any implications for refugees with respect to appeal to the Federal Court, a process independent of the claims procedure. Presently, refugee claimants whose application is turned down must seek leave to appeal the negative decision. Such leave is granted on matters of law involving presumed irregularities in due process and not on matters of new information which might alter the interpretation of the claim. The requirement to seek leave is now proposed for cases appealing decisions from abroad in order to bring consistency in such cases. Currently such applicants refused vi-

Refuge, Vol.18, No. 1 (February 1999) 
sas from abroad have direct access to appeals.

It thus appears that under the new recommendation claimants willexperience a speedier claims process but one whose administrative efficiency is balanced against rigour of outcome. Appeals against negative decisions will receivenonew relief. Chances of appeal remain highly restricted.

\section{Humanitarian Policy Orientation?}

Integral to any immigration policy at the apogee of the most destructive and terrifying century in human history should be the recognition of the crucial intervention of humanitarianism in the policy of the nation-state. There is at present no alternative to the nationstate as determiner, if not arbiter, of who shall be able to migrate $v$. those whose intentions and needs will not be fulfilled. This recognition must transcend prolegomena of compassion to those persecuted unjustly. Such recognition has to be integrated into every provision of entry and qualification for admission as a potential member of that state. Provisions of a policy statement must contain not only an overall sensitivity to issues of need but correlative administrative provisions to accommodate needs of forced migrants.

The present document separates the "protection" function for refugees from other immigration procedures. It provides few if any administrative means to embody this worthwhile division of function. Asnoted above, the term "protection" is nowhere defined, despite the fact that concepts and argumentation for such definition abound in the literature and are readily accessible.

New Directions neither states explicitly nor does it provide the groundwork for any provisions for Canada to accommodate persons who may "escape the net" of the generalUNHCRdefinition or whose conditions may otherwise arouse a particular humanitarian concern for Canada which might not be shared internationally. Yet Canada has already demonstrated such concern through administrative arrangements in the 1976 Immigration Act. The "Designated Class" provision refers to "refu- gee-like" situations in which Canada may opt to acceptcollectively groups of persons who categorically appear to be in a persecutory situation. Such cases are enumerated in an appendix to the Immigration Act and modified periodically as urgencies of persecution wax and wane. Such a provision was unique in immigration legislation at the time of its enactment. Yet the unceasing procession of crises beginning with the Indochinese persecutions to those throughout Eastern Europe, Middle East, Central America and more recently Africa have all relied on this form of aggregate decision-making in order to accelerate processing in light of international emergency.

There is no mention of how this provision or other administrative arrangement will provide recognition of peoplesin persecutory distress. There is no indication of how Canada might use its new immigration legislation proactively to search out situations and peoples whose condition demands immediate action of admission for resettlement. There is no statement which calls attention to Canada's continuing obligation to provide humanitarian assistance, nor an engagement to accommodate those who are caught in the untenable and dangerous if temporary state of victimization. Administrative accommodation for such persons and groups appears to be wanting.

Thus the New Directions paper appears unbalanced. It provides extensive detail in a separate chapter about security precautions, replete with recommendations for administrative implementation. No such detail is found in parallel to implement the humanitarian objectives to which the document refers in altogether general terms. The document therefore tilts toward exclusion as a guiding principle. The counterbalancing pressures for inclusion are inadequately addressed.

\section{Conclusion}

Implications for refugees in the recommendations contained in New Directions point to markedly improved administrative procedures. These recommendations contain implications for incorporation into revised legislation of the Immigration Act. For the most part, they are suggestive of legislative directions but lacking specificities normally expected in a White Paper.

The overall theme throughout the recommendations for refugee policy is that of enhancing protection, although the term and its implications are not explicated. Nevertheless, the importance of the state providing a protective function cannot be underemphasized as the distinguishing characteristic of refugee as distinguished from immigration policy in general. The recommendations are consistent with this overall theme.

In certain respects, the provisions appear to decentralize policy activity. The recommendations call for an increased role for NGOs, especially in overseas selection of appropriate cases requiring protection. Canada appears to wish to extend its scope beyond that afforded by a small cadre of overseas officials concentrated disproportionately in the developed rather than developing regions.

Thebalance of the recommendations, however, emphasize the necessity of government to centralize its decisionmaking and control over the process. Structurally, it proposes a single decision-making level, collapsing the former three levels of refugee status determination, post-determination risk review and risk-related humanitarian review. A single decision therefore indicates the government's final disposition on the case. Thus claimants and advocates are afforded only one opportunity for intervention in the determination process.

The overall thrust of the New Directions paper leads the reader to approve the circumspection with which the Canadian government approaches its international obligations of immigration intake. In so doing, it appears to be keeping pace with its European counterparts. The report remains silent, however, about its proactive role in protection for refugees and other forced migrants. Administrative implementation of this equally important goal lacks attention and specification. New Directions thus seems a misnomer: the 
direction in this work appears quite singular. $m$

\section{Notes}

1. This terminology appeared in several newspaper accounts as well as in a the Minister's address to the Third Conference on Immigration and Metropolis, Vancouver' 16 January 1999

2. France has allocated refugees to municipalities which houses arriving families for an initial period (e.g., six months) in a communalhostel arrangement. Thereafter, the municipality undertakes responsibility to find housing assure (welfare) subsidy, mor subsidy, placaton for childre (wel job search and the labour

3. The French version specifies as follows: pour permettre au ministre ( ... ) dechoisi des cas en vue de retirer son status a un refugie."

4. The French version likewise uses the conditional verb form: "Les criteres et Ie mode de selection, ainsi que Ie role et la composition du Comite consultatif ministeriel ( ... pourraient etre precises dans la legislation. "

\section{References}

Spencer-Nimmons, Noreen. 1994. "The Emergence of Refugee Women as a Social Issue: gence of Refugee Women as a Social Issue: versity. :J

\section{Refugee Rights:}

\section{Report on a Comparative Survey}

\section{By James C. Hathaway and John A. Dent}

Toronto: York Lanes Press, 1995; ISBN 1-55014-266-6; 82 pages; $\$ 11.95$

Are visa controls intended to keep refugees from reaching an asylum country legal? Can asylum-seekers legitimately contest conditions of detention? At what point do refugees have the right to work, or to claim social assistance?

These are among the many issues addressed by Refugee Rights: Report on a Comparative Survey, a ground-breaking analysis of the human rights of refugees around the world. Working in collaboration with thirty renowned legal experts from Europe, Africa, Asia, Oceania, North America, and Latin America, Professor James Hathaway, Osgoode Hall Law School, York University, and John Dent, Senior Research Associate, International Refugee Rights Project, Osgoode Hall Law School, York University, analyze the international legal instruments that set the human rights of refugees. By grounding their analysis in real-life challenges facing refugees today, Hathaway and Dent have produced a book as valuable to activists as to scholars.

Refugee Rights will provoke debate on the adequacy of the international refugee rights regime. It is essential reading for everyone concerned to counter threats to the human dignity of refugees.

$$
\text { Available from: }
$$

Centre for Refugee Studies

Fax: (416) 736-5837・Email: refuge@yorku.ca

\section{From Being Uprooted to Surviving: Resettlement of Vietnamese-Chinese "Boat People" in Montreal, 1980-1990}

\section{By Lawrence Lam}

Toronto: York Lanes Press, 1996; ISBN 1-55014-296-8, 200 pages, indexed; \$18.95

The saga of the "boat people" is a dramatic story, a story of one of the largest refugee movements in recent years. Canada played a significant role in the resettlement of these refugees in bringing them to Canada where they could start anew. From Being Uprooted to Surviving by Professor Lam, is based on ethnographic data of a sample of Vietnamese-Chinese accepted for resettlement in Montreal in 1979 and 1980, who were interviewed again in 1984-85 and in 1990-91, this book provides a longitudinal account of their experience of resettlement in Canada. This experience has been marked by successive stages of their struggle to overcome structural barriers and to negotiate a meaningful niche in Canada.

Contents: Preface, The Boat People Phenomenon, Resettlement-Issues and Perspectives, The Vietnamese-Chinese Refugees, Exodus and Transition, Resettlement Process-The First Three Years, Resettlement-Beyond the First Three Years, Conclusion.

$$
\text { Available from: }
$$

Centre for Refugee Studies Fax: (416) 736-5837 • Email: refuge@yorku.ca 